\title{
抗狭心症薬の二重盲検試験に関する 問題点について
}

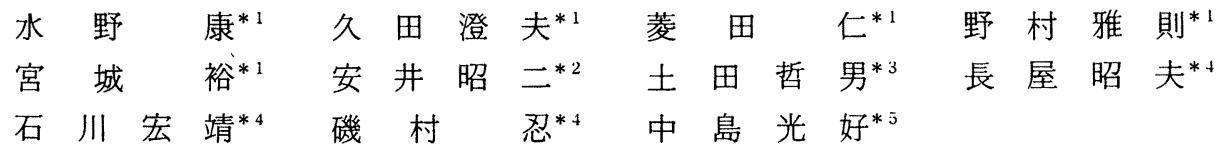

狭心症の治療薬として, いわゆる冠拡張薬が使 用されるようになって，すでに 15 年を経過する が，その効果についての評価は一定でない。

また狭心症は極めて漠然とした狭心痛によって 表現され，客観的にはとらえがたいもので，真の 狭心痛か否かの判定も困難である.

最近我国でも各種薬剂の効果判定に米国の Pharmaceutical Manufacturers Association の anti-anginal guidelines に準じて二重盲検試験が 行わ机ているが, 実際には数多くの問題点がある. 演者らも抗狭心症薬（冠拡張薬 $5, \beta$ ブロッカー 2 ）の二重盲検試験を行い, 幾つかの問題点に遭 遇したのでその一端について検討を試みた。

1. 対象 抗狭心症薬の試験対象としては, 狭 心症すべてにわたるべさであるが，冠硬化による 労作性狭心症を対象とした場合と, 安静狭心症と くに夜間狭心症, 異型狭心症を対象とした場合で はその薬の性質により結果は大いに異なる。 $\beta$ ブ ロッカーは労作性狭心症により有効であり, $\mathrm{Ca}^{+-}$ 拮抗性冠拡張薬は安静狭心症とくに冠硬化の著し

*1 名古屋保健衛生大学内科

*2 名古屋大学医学部第一内科

*3 名古屋東市民病院

*4 安城更生病院

$* 5$ 浜松医科大学薬理

くない異型狭心症に特異的に有効である. 従って 薬理作用によりどの狭心症を対象とするかにより 効果は大いに異なる.

2. 狭心痛の判定 狭心痛は SAVES の特徵を 有するものとされるが，漠然とした不快感といら 特徵が示すように, 不整脈, 心不全などの他の心 機能不全からの症状とまぎらわしく，患者は混同 して訴える。また患者の日常動作の程度（質と量） によって変化し，患者日誌を如何に工夫しても， 患者の動作と狭心痛の推移を関係づけて, かつ薬 の効果を判定することは困難である. このため服 用より一定時間における運動耐容量を測定するこ とも考慮されているが，薬物の薬理作用によって はこの判定法は不利となる恐れもある.

3. 心電図所見 狭心症の客観的診断法として 心電図の ST 降下, T陰転は極めてよい示標でめ り, 二重盲検試験でも広く利用されている. しか しながら狭心痛と ST-T 変化は必ずしも量的, 時 間的に比例せず, ST-T 変化が病態により固定し て不変のものと, 自然変動が強く, 日常労作で容 易に大さく変動するものなど，さむざあである. ST 降下の測定法も問題で, ST.J または ST $0.04 "$ が測定されているが，J点は判然としないことが 多い.ST の異常の程度にはミネソタコードまた は日循協の分類が使用されているが，これらはい 
ずれもフィールドにおける borderline の症例を 対象とした分類で，病院に扣けるＳT 降下の強い 対象には不適当なことが多い。をた虚血型 ST 降 下と J 型 ST 降下の区別, いずれが重症かの判定 も困難なことが多い，心電図による運動耐容量も 使用されているが，実際にあたってかなりの問題
がある。

4. 効果判定 主治医判定, 総合判定, 有用度 判定など判定尺度は一定せず，客観的と思われる 心電図改善度も実際には極めて不正確と考えられ る.これら効果判定についても問題点を挙げる. 